\title{
Impersonal constructions in Slavic languages and the agentivity of the verb
}

0 . This paper presents the results of a small explorative corpus study designed to test the hypothesis that the grammaticality of arb constructions depends on the agentivity of the implicit subject entailed by the verb. This study was conducted in the context of project B01 "Prominence phenomena in Slavic languages" of the Collaborative Research Centre 1252 "Prominence in Language", which is funded by the German Research Foundation (DFG), and in close cooperation with project B07 "Agentivity as a key to prominence: Experimental approaches to argument alternations in German" led by Beatrice Primus and Markus Philipp. After clarifying what I mean by arbs (1.), I will explain the notion and operationalization of agentivity (2.), describe the method (3.) and discuss the results (4.) of the corpus study.

1. All the Slavic languages have a certain type of impersonal constructions with a demoted subject with reduced referentiality and an arbitrary interpretation, which correspond to constructions with German man or French on. In particular, these are the so-called -no/-to construction as in (1), the reflexive impersonal as in (2) and the third person plural impersonal as in (3).

(1) Tańczo-no do biatego rana. dance-PST.IMPRS until white morning 'People danced until dawn.' (Krzek 2014, 133)

(2) Spava se na podu. sleep:3SG REFL on ground

(Serbo-Croatian) 'One sleeps on the ground.' (Siewierska 1988, 265)

(3) Ego uvažaj-ut. him.ACC honour-3PL

(Russian) 'People honour him.' (Švedova 1980, §2515)

There is no cover term for these constructions that is commonly accepted in linguistics. The term often used in Slavic linguistics, indeterminate-personal sentences (from Russian neopredelënno-ličnye predloženija, e.g. Padučeva 2012, Švedova 1980, §1525), is unfortunate because these constructions, lacking a canonical subject, are clearly impersonal in the widely accepted sense of Siewierska 2008, 116. Neither are these constructions necessarily indefinite as the Russian term implies (cf. Berger 1991, 72): Gast \& van der Auwera 2013, 26 distinguish between definite and indefinite reference, and Malamud 2013, 22 states that the Russian 'in- 
determinate-personal' construction is "semantically similar to definite plurals". She proposes the term arbs (which is short for "constructions with arbitrary interpretations"), and I will follow her proposal.

The notion of "arbitrary interpretation" encompasses several distinct readings, which Cabredo-Hofherr 2003, 83 classifies as follows (cf. Gast \& van der Auwera 2013 for an extended account):

(I) specific existential reading (temporally anchored) [...]

(II) vague existential reading (not temporally anchored) $[\ldots]$

(III) inferred existential reading (inferred from a result) [...]

(IV) corporate reading (predicates with a designated subject) [...]

(V) universal reading (licensed by a locative)

I propose to restrict the term arb to only those grammaticalized impersonal constructions that cover at least some of the readings I-IV. Reading V is covered by many other constructions that have nothing to do with arbitrary interpretations because the universal (generalized, generic) reading can easily be achieved by metaphor, e.g. from 'you', 'we', etc. as in (4) or from a generic noun like 'people', etc. as in (5):

(4) Tebja ne ubed-išs you:ACC not convince:PF-FUT.2SG

'You cannot be convinced.' (Kubík 1974, 56)

(5) Tebe člověk ne-předsvědč-í.

you:ACC human.being:NSG not-convince:PF-FUT.2SG

(Russian)

'You cannot be convinced.' (ibid.)

These expressions cannot have any of the readings I-IV and are therefore no arbs. In a similar way, the universal reading also has to be regarded as a metaphorical extension of the existential readings in arbs ('an arbitrary person' $\rightarrow$ 'everyone').

Note that the effect of agent demotion can be achieved by other means as well, most notably by passives. Since canonical passives have a regular subject (although it is not the agent), they are not impersonal constructions and therefore cannot be classified as arbs (cf. Malchukov \& Ogawa 2011, 36-38). However, "impersonal passives" like the German one (cf. Primus 2011; Gast \& van der Auwera 2013, 124) can be classified as arbs. The "-ne/-te construction" described by Kibort (2011) might also be considered an impersonal passive (cf. Malchukov \& Ogawa 2011, 37), although its use seems to be restricted to "verbs denoting household activities" (Kibort 2011, 363). Apart from that, there are special constructions that express modal meanings (corresponding to modal verbs in English) with an arbitrary agent, e.g. Russian nado 'one has to' or Polish można 'one can'. These constructions could be classified as modal arbs. However, they will not be considered in this paper. 
Constructions like the ones illustrated in (1)-(3) exist in all Slavic languages. For example, Polish has all three types of constructions: the so-called -no/-to construction as in (1), the impersonal reflexive as in (6), and the $3 \mathrm{pl}$ impersonal as in (7) (although the use of the latter is rather restricted and marked as colloquial).

(6) Da sie wszystk-im prezent-y.

(Polish) give.FUT.3SG REFL everybody-DAT presents-ACC 'One will give everybody presents.' (Krzek 2011, 68)

(7) Znowu podnieś-l-i cen-e paliw-a. again raise-PST-3PL.VIR price-ACC fuel-GEN 'They have raised the fuel price again.' (Kibort 2008, 263)

The Russian language has only one general arb construction, the $3 \mathrm{pl}$ impersonal as in (3). In Serbo-Croatian the reflexive impersonal as in (2) is the most usual construction but the $3 \mathrm{pl}$ impersonal occurs as well:

(8) Kaž-u da je to davno bi-l-o. (Serbo-Croatian) say-3PL COMP AUX.3SG it long.ago be-PST-N.SG 'They say it happened long ago.' (Milićević 2013, 171)

These constructions are firmly established in descriptive grammars (e.g. Laskowski 1984, 147; Bartnicka et al. 2004, 355; Švedova 1980, §1525; Težak \& Babić 1994, $\S 618$ ), although the more colloquial alternatives (e.g. the 3pl impersonal in Polish and Serbo-Croatian) are sometimes neglected. Apart from that, the arb constructions have also been the object of numerous special linguistic studies. Many of them have concentrated on a certain type of construction, e.g. 3pl impersonals (e.g. Siewierska \& Papastathi 2011) or reflexive impersonals (e.g. Rivero \& Milojević Sheppard 2001; Meyer 2010; Krzek 2011). With respect to the restrictions of the Slavic arb constructions, all the researchers agree that they can only be used with an implicit subject that is obligatorily [+ human] (Mel'čuk 1974, 350; Švedova 1980, §1525; Padučeva 2012, 29; Laskowski 1984, 147; Kątny 1999, 660; Rivero \& Milojević Sheppard 2001, 140; Sansò 2006, 255; Kibort 2008, 267; etc.). As Kibort 2008, 272 has shown, for the Polish reflexive impersonal the default [+ human] interpretation can be overridden by a context suggesting a non-human animate subject; however, the construction cannot refer to inanimates (the subject has to be [+ conscious], as Krzek 2011, 71f. defines it). In contrast to this, in the -no/-to construction the feature [+ human] cannot be overridden (Kibort 2008, $267,272)$. As to the type of verbs that can form arbs, it is often noted that in contrast to passives, arbs can be formed from all verbs, including both unergative and unaccusative intransitive verbs (Kibort 2008, 265, 271; Krzek 2011, 68-69; cf. already Małecki 1879, 445).

2. My hypothesis is that the grammaticality of arb constructions does not depend on the animacy of the implicit agent alone but that some verbs are better than oth- 
ers, and some are rather unacceptable even with human agents. I assume that the availability and acceptability of the arb constructions depends on agentivity and that this dependence has the form of a prominence relation in the sense of Himmelmann \& Primus 2015.

The notion of agentivity has recently undergone considerable changes. While traditionally the agent was seen as a more or less monolithic role within the hierarchy of roles in a sentence (including patient, experiencer, etc.), Dowty 1991, 572 gives a "preliminary list" of four entailments characterizing a prototypical agent ("proto-agent"), thus allowing for less prototypical and peripheral agents that exhibit only some of these features: volition, sentience, causation and movement. While the set of features as well as their exact status are still under discussion (e.g. Primus 1999; 2011), it seems to be widely accepted that there are more agentive and less agentive verbal arguments and that agentivity should therefore be decomposed into several features.

As a test of our hypothesis we use three of Dowty's 1991 agentivity features volition, sentience and movement - to form four classes of intransitive verbs with different degrees of agentivity:

1. 3 features: [+ volition] [+ motion] [+ sentience]

2. 2 features: [- volition] [+ motion] [+ sentience]

3. 1 feature: [- volition] [- motion] [+ sentience]

4. 0 features: [- volition] [- motion] [- sentience]

Note that by choosing these features we do not make any statement about the (in)dependence of the features from each other. Specifically, they do not seem to form an implicational scale. Consequently, with these three features $2 \times 2 \times 2=8$ combinations are theoretically possible, and indeed at least some of the other four combinations certainly exist (e.g. 'wait', 'think', 'listen', etc. have the features [+ volition] [- motion] [+ sentience]). However, the only aim of this selection of features is to achieve classes of verbs with different numbers of features.

For each of the four verb classes five Polish and five Serbo-Croatian verbs were selected:

1. tańczyć/plesati 'dance', spacerować/šstati 'stroll', rozmawiać/razgovarati 'talk', plotkować/pričati 'gossip', szeptać/šaputati 'whisper'

2. padać/padati 'fall', kichać/kihati 'sneeze', drżeć/drhtati 'shiver', kaszleć/kašljati 'cough', krwawić/krvariti 'bleed'

3. cierpieć/patiti 'suffer', watpić/dvojiti 'doubt', zależećlovisiti 'depend', umieraćlumirati 'die', ptakać/plakati 'cry'

4. śmierdzieć/smrdjeti 'stink', cuchnać/zaudarati 'smell bad', pochodzić/proizlaziti 'originate', lśnić/sjati 'glisten', btyszczeć/blistati 'shine'

I chose verbs with very similar meanings in Polish and Serbo-Croatian to increase the comparability of the results; however, in most cases there is no absolute synon- 
ymy. The English translations given above are merely meant for orientation and do not cover the whole range of meanings in which the verbs are used in the corpora.

All the verbs are imperfective. None of them is reflexive because in Polish the reflexive impersonal cannot be formed from inherently reflexive verbs (Siewierska 1988, 265). In Serbo-Croatian, reflexive verbs do form the reflexive impersonal by merging the lexical reflexive pronoun and the grammatical reflexive pronoun into one (cf. Jernej 1997, 106f.). However, these forms are homonymous with regular personal (referential, active) forms. All the verbs chosen are intransitive (i.e. they do not govern an accusative object) so that they cannot form canonical passives, which would cause additional ambiguities.

3. To test the hypothesis, an explorative corpus study was conducted. The expectation was that the frequency of the arb constructions in the corpus would be proportional to the number of agentivity features entailed by the verb.

Since the corpus study aims at detecting significant differences in the frequencies of relatively infrequent constructions of individual verbs we need large corpora for this task. Therefore I chose two web corpora which are available at the Aranea project: the Araneum Polonicum Maius (version 1.3; 786 million words, 1.2 billion tokens; Benko 2014) and the $h r W a C$ (version 2.0; 858 million words, 1.2 billion tokens; Ljubešić \& Klubička 2014).

The frequency of the Polish -no/-to construction was revealed by a word-form search for tańczono, cuchnięto, etc. Since these forms are unambiguous (the nominative singular neuter form of the passive participle from which the form is derived does not have the ending - $o$ anymore; instead, the participle nowadays ends in -ne/-te), the number of hits returned is usually the exact frequency, without false positives or false negatives. The single major exception was padano "(they/people) fell', which occurred 55 times in the name of the Italian cheese Grana Padano (and three times as a misspelling of podano '(they/people) gave').

The reflexive impersonal construction in Polish and Serbo-Croatian is much harder to find in the corpus. I decided to use a search algorithm that reduces the number of false positives to a minimum at the expense of a possibly large number of false negatives: I only looked for the preterit (i.e. the $l$-participle), third person singular neuter, neglecting all instances of the reflexive impersonal in the present, future, and conditional (and possibly in the Serbo-Croatian aorist and imperfect), and I only looked for this form with the reflexive pronoun directly before or after it (i.e. the search terms were tańczyto się, się tańczyło, etc. for Polish and plesalo se, se plesalo, etc. for Serbo-Croatian). When considering the numbers given for the reflexive impersonal it should therefore be kept in mind that the real frequency of this construction is likely to be considerably higher.

The 3pl impersonal was not included in the corpus study. In Polish and SerboCroatian it is completely homonymous with the regular 3PL of the verb. The ab- 
sence of an explicit subject does not distinguish it from a sentence with anaphoric reference because both Polish and Serbo-Croatian are pro-drop languages. In Russian, where anaphoric reference generally has to be expressed by a pronoun, and impersonal tancevali '(they/people) danced' is therefore distinct from referential oni tancevali 'they danced', I made attempts to search for the $3 \mathrm{pl}$ impersonal by excluding all hits with a nominative form within the five preceding and the five following words. However, the number of false positives is still so high that I decided not to include this form in the present corpus study either. The Russian and Polish 3pl impersonal will be examined later, using qualitative corpus studies and acceptability judgement tests.

Of course, the absolute numbers of occurrences are not very meaningful because they depend on the overall frequency of the verbs chosen. Therefore I determined the frequency of the respective lemmas (which was facilitated by the fact that both corpora are lemmatized ${ }^{1}$ ) and computed the ratio of the frequency of the impersonal constructions to the overall frequency of the verb.

A few of the hits returned by the corpora had to be discarded. For example, I took care to use only those verbs that were given as non-reflexive by the dictionaries; however, some of these verbs (Polish btyszczeć 'shine', krwawić 'bleed'; Serbo-Croatian blistati 'shine', sjati 'glisten', padati 'fall') were used with a lexical reflexive pronoun in a few instances, e.g. Serbo-Croatian djetinjsko lice sjalo se od radosti 'the child's face was shining with joy', Nije mi se padalo na pamet raspakiravati 'It did not come (lit.: fall) to my mind to unpack', Polish Jego serce chrześcijańskie [...] krwawiło sie na widok tej krzyczacej niesprawiedliwości 'His Christian heart [...] was bleeding at the sight of this crying injustice'. In very few cases, the web corpora contained 'doorway pages' without real information but with real-looking nonsensical texts created by a Markov chain content generation program, e.g. huffington $w$ informuje $w$ za $w$ od akcji sie zależato, sonntagszeitung po pedofilów rzadzić sit podziaty wspierać podziękować się. Other sources of error, like misspellings or adjacency problems (as in Polish nie chciała, żeby coś na czym tak bardzo jej zależato się skończyło 'she did not want something that meant so much to her to be over', where the reflexive pronoun belongs to skończyć 'end', not to zalezecé 'depend'), play only minor roles.

A remaining problem that could not be solved concerns lemmatization. Since the corpora have not been disambiguated manually, morphological homonyms are included when determining the frequency of a lexeme. For example, some forms of the noun priča 'narration' are homonymous with forms of the verb pričati 'talk, gossip' and are therefore counted as instances of this verb, which mathematically

\footnotetext{
${ }^{1}$ Strangely, the Polish verb plotkować was not lemmatized (i.e. a lemma search for plotkować yielded only the infinitive), so the lemma frequency had to be added up from the frequencies of all the forms of the verb, including the participles and the verbal noun.
} 
diminishes the relative frequency of the respective arb. All in all, however, this effect does not seem to have distorted the results too much.

4. The results of the corpus research are presented in fig. 1 (showing the relative frequencies; the absolute numbers are given in fig. 2). The difference between the verbs in class I ('dance' etc.) and the other verbs is eye-catching. While there is considerable variation within the class - a lexical meaning like 'gossip' of course lends itself very much to impersonalization -, it is clear that the most agentive verbs are most frequently used with arbs. The relatively low values for 'stroll' might even, in a manner of speaking, be attributed to reduced volitionality, because strolling involves a certain aimlessness.

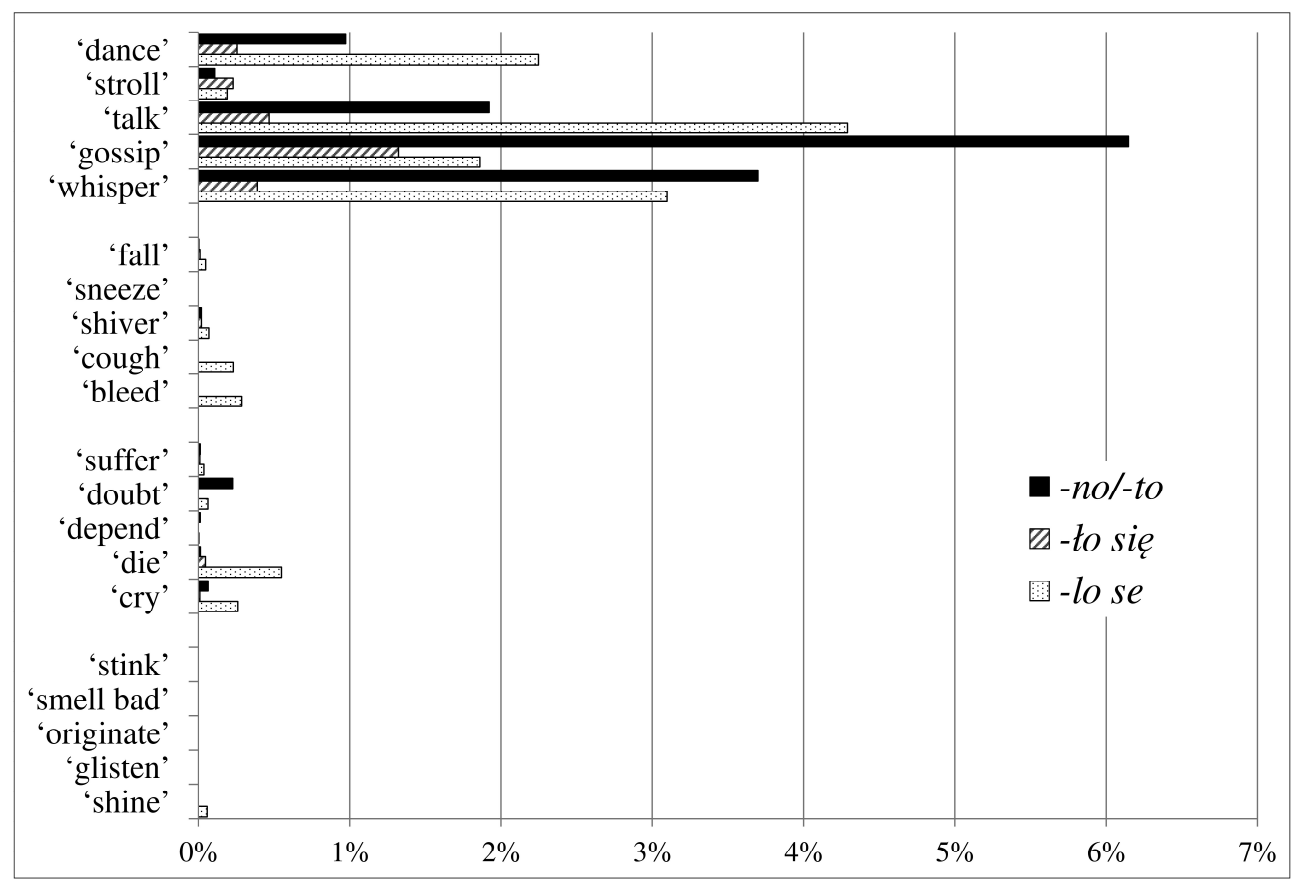

Fig. 1: Relative frequencies of arbs for 20 verbs

It is also obvious that the verbs of class IV ('stink') are not used in arb constructions at all (the only exception in two gigaword corpora being a single instance of the verb blistati 'shine' used in a metaphorical sense, which makes the implicit subject agentive: Ali nije se blistalo samo na seniorskom veslačkom prvenstvu SFRJ 1974. 'But they shone (i.e. performed brilliantly) not only at the Yugoslav Masters Rowing Championship of 1974'). In contrast to this, in classes II and III all verbs with a frequency of 1.5 per million and higher occur in an arb construction at least once. 


\begin{tabular}{|c|c|c|c|c|c|c|c|}
\hline Verb & $\begin{array}{l}\text { Polish } \\
\text { lexeme }\end{array}$ & $-n o /-t o$ & -to się & sie -to & $\begin{array}{l}\text { Serbo- } \\
\text { Croatian } \\
\text { lexeme }\end{array}$ & -lo se & se-lo \\
\hline 'dance' & 14884 & 145 & 15 & 23 & 19310 & 274 & 160 \\
\hline 'stroll' & 7398 & 8 & 8 & 9 & 16237 & 7 & 24 \\
\hline 'talk' & 60813 & 1169 & 92 & 192 & 100201 & 2421 & 1878 \\
\hline 'gossip' & 1285 & 79 & 7 & 10 & 137745 & 1145 & 1418 \\
\hline 'whisper' & 2055 & 76 & 7 & 1 & 1033 & 13 & 19 \\
\hline 'fall' & 28423 & 1 & 1 & 2 & 76632 & 20 & 17 \\
\hline 'sneeze' & 120 & 0 & 0 & 0 & 169 & 0 & 0 \\
\hline 'shiver' & 4911 & 1 & 0 & 1 & 1427 & 0 & 1 \\
\hline 'cough' & 739 & 0 & 0 & 0 & 1298 & 1 & 2 \\
\hline 'bleed' & 1036 & 0 & 0 & 0 & 3146 & 2 & 7 \\
\hline 'suffer' & 41002 & 5 & 0 & 4 & 30471 & 2 & 9 \\
\hline 'doubt' & 9710 & 22 & 0 & 0 & 18838 & 2 & 10 \\
\hline 'depend' & 8106 & 1 & 0 & 0 & 84098 & 0 & 3 \\
\hline 'die' & 21151 & 3 & 8 & 2 & 17655 & 27 & 70 \\
\hline 'cry' & 20026 & 13 & 0 & 2 & 20368 & 16 & 37 \\
\hline 'stink' & 4223 & 0 & 0 & 0 & 8221 & 0 & 0 \\
\hline 'smell bad' & 471 & 0 & 0 & 0 & 694 & 0 & 0 \\
\hline 'originate' & 130971 & 0 & 0 & 0 & 28243 & 0 & 0 \\
\hline 'glisten' & 1312 & 0 & 0 & 0 & 2878 & 0 & 0 \\
\hline 'shine' & 3837 & 0 & 0 & 0 & 1718 & 0 & 1 \\
\hline
\end{tabular}

Fig. 2: Absolute frequencies in the two corpora

However, the difference between classes II ('fall') and III ('suffer') is clearly not significant. Since these two classes were designed to differ only in the feature [ \pm movement], this feature does not seem to be substantial at least for the explanation of the use of arb constructions and in the straightforward sense of self-propelled physical movement in which it has been applied so far. (Remember, however, that we have not investigated all possible feature combinations; it is still possible that verbs of class I with [+ volition] [+ movement] are more agentive and thus more inclined to arbs than verbs with [+ volition] [- movement], which we have not tested yet.)

In contrast to class IV, the verbs of class II and III are used in spite of their low agentivity, e.g. Polish Kiedyś umierato się w wieku lat 30! 'Once people used to die in their thirties!' or Serbo-Croatian Na prvoj pokusnoj projekciji svi su ostali sjediti $i$ nakon što su se upalila svjetla. Puno se plakalo 'At the first preview all remained seated even after the lights went on. There was a lot of crying'. However, many of the occurrences summed up in fig. 1 are instances of a volitional reinterpretation, e.g. Polish Ściskano się, brano w ramiona, padano damom do nóg i płakano z rozczulenia 'People hugged, embraced, fell at the ladies' feet and were moved to tears'. Sometimes the action is not completely volitional but the context implies that the implicit subject permits something to happen, e.g. Polish Niektórzy pacjenci nie chca, by ptakano przy nich 'Some patients do not want people to cry in their presence'. In other cases, while the action as such is not volitional, the way it hap- 
pens can be influenced, e.g. Serbo-Croatian Neoprane ruke, u koje se kašljalo ili kihalo, pune su klica 'Unwashed hands, into which one has coughed or sneezed, are full of germs'. Another context of increased agentivity is the voluntary acceptance of suffering, e.g. Serbo-Croatian Zbog tog glupog osjećaja su se vodili ratovi $i$ bitke. Umiralo se zbog ljubavi 'For this stupid feeling wars and battles were fought. People died for love'. Quite often, involuntary reactions are used metaphorically as an expression of emotions, e.g. Serbo-Croatian Nisu to cipele zbog čije ljepote bi se padalo u nesvijest 'These are no shoes from whose beauty one would fall unconscious'.

5. The results of this little corpus study clearly show that agentivity of the implicit subject as entailed by the lexical meaning of the verb lexeme plays a decisive role for the applicability of arb constructions, even with human implicit subjects. The fact that the context seems to have a considerable influence on the interpretation especially of volitionality shows the "context-dependent shift", which was identified by Himmelmann \& Primus 2015, 48-50 as a characteristic of prominence relations.

\section{References}

Bartnicka, B. et al. 2004. Grammatik des Polnischen. München.

Benko, Vl. 2014. Aranea: Yet another family of (comparable) web corpora. In: Sojka, P. et al. (eds.). Text, speech and dialogue: 17th international conference, TSD 2014, Brno, Czech Republic, September 8-12, 2014. Berlin, 257-264.

Berger, T. 1991. Zum denotativen Status „unbestimmt-persönlicher“ Konstruktionen im Tschechischen. In: Grochowski, M., D. Weiss (eds.). "Words are physicians for an ail-

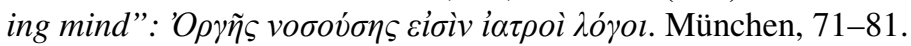

Cabredo Hofherr, P. 2003. Arbitrary readings of 3 pl pronominals. In: Weisgerber, M. (ed.). Proceedings of Sinn und Bedeutung (SuB) 7. Konstanz, 81-94.

Dowty, D.R. 1991. Thematic proto-roles and argument selection. Language 67 (3), 547-619.

Gast, V., J. van der Auwera. 2013. Towards a distributional typology of human impersonal pronouns, based on data from European languages. In: Bakker, D. et al. (eds.). Languages across boundaries: Studies in memory of Anna Siewierska. Berlin, 119-158.

Himmelmann, N., B. Primus. 2015. Prominence beyond prosody - a first approximation. In: De Domenicis, A. (ed.). pS-prominenceS: Prominences in linguistics. Proceedings of the international conference, Viterbo, Italy, 12-14 December 2013. Viterbo, 38-58.

Jernej, J. 1997. O bezličnim povratnim tvorbama u hrvatskom jeziku. Suvremena lingvistika 43-44 (1-2), 105-107.

Kątny, A. 1999. Das Verb. In: Engel, U. et al. Deutsch-polnische kontrastive Grammatik. Heidelberg, 541-697.

Kibort, A. 2008. Impersonals in Polish: An LFG perspective. Transactions of the Philological Society 106 (2), 246-289.

- 2011. The elephant in the room: The impersonal -ne/-te construction in Polish. In: Malchukov, A., A. Siewierska (eds.). Impersonal constructions: A cross-linguistic perspective. Amsterdam, 357-394. 
Krzek, M. 2011. Impersonal się constructions in Polish. Newcastle Working Papers in Linguistics 17, 67-93.

- 2014. The structure of null subject DPs and agreement in Polish impersonal constructions. In: Bondaruk, A., G. Dalmi, A. Grosu (eds.). Advances in the syntax of DPs: Structure, agreement, and case. Amsterdam, 129-163.

Kubík, M. (ed.). 1974. Sintaksis russkogo jazyka. Praha.

Laskowski, R. 1984. Kategorie morfologiczne języka polskiego - charakterystyka funkcjonalna. In: Grzegorczykowa, R., R. Laskowski, H. Wróbel (eds.). Morfologia. Warszawa, 121-170. (Gramatyka współczesnego języka polskiego. 2.)

Ljubešić, N., F. Klubička. 2014. \{bs,hr,sr $\}$ WaC - Web corpora of Bosnian, Croatian and Serbian. In: Bildhauer, F., R. Schäfer (eds.). Proceedings of the 9th web as corpus workshop (WaC-9)@EACL 2014. Gothenburg, 29-35.

Malamud, S.A. 2013. (In)definiteness-driven typology of arbitrary items. Lingua 126, 1-31.

Malchukov, A., A. Ogawa. 2011. Towards a typology of impersonal constructions: A semantic map approach. In: Malchukov, A., A. Siewierska (eds.). Impersonal constructions: A cross-linguistic perspective. Amsterdam, 19-56.

Małecki, A. 1879. Gramatyka historyczno-porównawcza języka polskiego. Lwów.

Mel'čuk, I.A. 1974. O sintaksičeskom nule. In: Xolodovič, A.A. (red.). Tipologija passivnyx konstrukcij: Diatezy i zalogi. Leningrad, 343-361.

Meyer, R. 2010. Reflexive passives and impersonals in North Slavic languages: A diachronic view. Russian Linguistics 34, 285-306.

Milićević, J. 2013. Impersonal constructions in Serbian: A description within a Meaning $\Leftrightarrow$ Text linguistic model. In: Kor Chahine, I. (ed.). Current Studies in Slavic Linguistics. Amsterdam, 169-184.

Padučeva, E.V. 2012. Neopredelenno-ličnoe predloženie i ego podrazumevaemyj sub"ekt. Voprosy jazykoznanija 1, 27-41.

Primus, B. 1999. Cases and thematic roles: Ergative, accusative and active. Tübingen.

- 2011. Animacy and telicity: Semantic constraints on impersonal passives. Lingua 121 (1), 80-99.

Rivero, M.L., M. Milojević Sheppard. 2001. On impersonal se/się in Slavic. In: Zybatow, G. et al. (eds.). Current issues in formal Slavic linguistics. Frankfurt am Main, 137-147.

Sansò, A. 2006. 'Agent defocusing' revisited: Passive and impersonal constructions in some European languages. Typological Studies in Language 68, 232-273.

Siewierska, A. 1988. The passive in Slavic. In: Shibatani, M. (ed.). Passive and voice. Amsterdam, 243-289.

- 2008. Introduction: Impersonalization from a subject-centred vs. agent-centred perspective. Transactions of the Philological Society 106 (2), 115-137.

Siewierska, A., M. Papastathi. 2011. Towards a typology of third person plural impersonals. Linguistics 49 (3), 575-610.

Švedova, N.Ju. (red.). 1980. Russkaja grammatika. 2 vols. Moskva.

Težak, St., St. Babić. 1994. Gramatika hrvatskoga jezika: Priručnik za osnovno jezično obrazovanje. $10^{\text {th }} \mathrm{ed}$. Zagreb.

Köln

Daniel Bunčić

(daniel.buncic@uni-koeln.de) 